\title{
Cristinel Munteanu
}

\section{Reply to Javier de la Higuera's Comments}

Mr. Javier de la Higuera's comments are welcome, since they allow me to give further clarifying (hopefully) remarks. I have to mention that, while referring to cultural objects, I have always called to mind the definition that Coseriu himself gave to culture (obviously, it started from Hegel, as well as from Aristotle) in a lecture delivered in Romanian in the '90s (entitled The Deontology of Culture). Consequently, I do not consider I have distanced myself from Coseriu's conception on culture and thus on language. I hope the definition given below, which belongs to Coseriu, fully satisfies Mr. Javier de la Higuera, since it includes all the elements he referred to:

Culture is the historical objectivization of spirit into forms which last, into forms which become traditions, historical forms which describe the world specific to humans, the human's specific universe. What do we mean by spirit, what is objectivized in history as culture? It is the creative activity, it is creativity itself, not something that creates, but creative activity as such, enérgeia, that specific activity which is anterior in concept to any dynamism, to any acquired or experimented technique. [...] The creative activity itself is a free activity, in the philosophical sense of the word «free», that is an activity whose object is infinite. (Coşeriu 1994: 173). ${ }^{1}$

Mr. Javier de la Higuera goes on saying, among other things, that: "Philosophy is not only limited to represent its object, but also has to build it in a speculative way, as an object-problem. That speculative construction of the object is, partly, what cultural sciences are forced to make". Similarly, in order to add to Mr. Javier de la Higuera's ideas, I would like to mention Eugenio Coseriu's opinion regarding the creation of objects by their corresponding sciences, that is why I would rather quote a paragraph from Lecciones de lingüística general:

A este respecto se repite a menudo en los últimos tiempos la afirmación ambigua de F. de Saussure de que «el punto de vista crea el objeto», afirmación que, además, se interpreta en un sentido que no puede tener y que justificaría cualquier planteamiento. Pero no hay que ceder a la tentación. El punto de vista no crea, desde luego, los objetos como tales (salvo en el caso de los objetos matemáticos): «crea» los objetos de las ciencias, y no en cuanto a sus rasgos reales, sino en el sentido de que los selecciona y los delimita dentro de los objetos de la experiencia corriente. Y esta delimitación no es ni arbitraria ni convencional, ya que se ajusta a la finalidad de cada ciencia y, en el caso de los objetos culturales, también, y en primer lugar, al saber intuitivo acerca de lo universal de estos objetos. (Coseriu 1981: 124).

1 In the original version: „Cultura este obiectivarea istorică a spiritului în forme care durează, în forme care devin tradiţii, devin forme istorice care descriu lumea proprie a omului, universul propriu al omului. Şi ce numim spirit, adică ceea ce se obiectivează în istorie sub formă de cultură? Este activitatea creatoare, este creativitatea însăşi, nu ceva care creează, ci activitatea creatoare ca atare, enérgeia, acea activitate care este anterioară conceptual oricărui tehnici învăţate sau experimentate. [...] Activitatea creatoare ea însăşi este o activitate liberă, în sensul tot filozofic al cuvântului liber, adică o activitate al cărei obiect este infinit" (Deontologia culturii, in Coşeriu 1994: 173). 